\title{
Protein requirements and ageing: metabolic demand and efficiency of utilization*
}

\author{
BY A. FEREDAY ${ }^{1}$, N. R. GIBSON ${ }^{1}$, M. COX $^{1}$, P. J. PACY ${ }^{2}$ AND D. J. MILLWARD ${ }^{1} \dagger$ \\ ${ }^{1}$ Centre for Nutrition and Food Safety, School of Biological Sciences, University of Surrey, Guildford \\ GU2 $5 X H$ \\ ${ }^{2}$ Unit of Metabolic Medicine, St Mary's Hospital, Praed Street, London W2 IPG
}

(Received 26 September 1996 - Revised 16 December 1996 - Accepted 23 December 1996)

\begin{abstract}
The protein requirements of the elderly were investigated with $\left[{ }^{13} \mathrm{C}\right]$ leucine balance studies of metabolic demand, the efficiency of postprandial protein utilization (PPU) and the consequent apparent protein requirement. Ten elderly subjects aged 68-91 years (five men and five women) and ten young adult subjects aged 21-31 years (five men and five women) were infused with $L$ $\left[1-{ }^{13} \mathrm{C}\right]$ leucine for $9 \mathrm{~h}$ commencing in the postabsorptive state $(0-3 \mathrm{~h})$, continuing during the halfhourly feeding of low-protein meals (LP; protein 3\% energy, 3-6h), and during similar feeding of isoenergetic higher protein meals (HP; protein $15 \%$ energy, 6-9h). Leucine oxidation and balance were determined from plasma $\left[1-{ }^{13} \mathrm{C}\right]$ - $\alpha$-ketoisocaproate enrichment and expired ${ }^{13} \mathrm{CO}_{2}$ excretion measured during the 3rd hour of each $3 \mathrm{~h}$ period. The protein intake during the HP phase was similar to the habitual intake estimated in the subjects from $24 \mathrm{~h}$ urinary $\mathrm{N}$ excretion. Metabolic demand was defined as equal to twice the body-protein equivalent of measured postabsorptive leucine oxidation. The efficiency of PPU was calculated from the increased leucine oxidation observed during feeding, and the apparent protein requirement was defined as metabolic demand/ PPU and calculated in relation to both body weight (BW) and fat-free mass (FFM) determined by densitometry or bioimpedance. Metabolic demand in the young adults was $0.83 \mathrm{~g}$ protein/kg per d; in both elderly groups it was $36 \%$ lower when expressed per $\mathrm{kg} \mathrm{BW}$ and $30 \%$ lower when expressed per kg FFM. The apparent protein requirement calculated from metabolic demand and PPU was $0.99 \mathrm{~g}$ protein $/ \mathrm{kg}$ per $\mathrm{d}$ in the young adults and this was also lower in the elderly, although this was only significant in the men $(0.66 \mathrm{~g}$ per $\mathrm{kg} B W, P=0.013 ; 0.79 \mathrm{~g}$ per $\mathrm{kg} F F M, P=0.02)$. The results show that in this group of healthy elderly adults protein requirements as assessed from leucine balance studies were either similar to or less than those of younger adults.
\end{abstract}

Elderly: Protein requirements: Leucine oxidation

The elderly represent an important yet poorly understood population group as far as nutritional requirements are concerned. We are concerned here with their protein requirements. Current nutritional recommendations for protein for the elderly in the UK and most other countries derive from the recommendations of the 1985 Food and Agriculture Organization/World Health Organization/United Nations University (FAO/WHO/UNU) Expert Consultation (FAO/WHO/UNU, 1985). On the basis of somewhat limited $\mathrm{N}$ balance data the consultation concluded that healthy elderly people have a dietary protein requirement that is not less than the need established for younger adults, i.e. a mean protein requirement of $0.6 \mathrm{~g} / \mathrm{kg}$ and a safe intake of $0.75 \mathrm{~g} / \mathrm{kg}$. Recognizing the reduced amount of lean tissue in this group they commented 'This figure is higher than that for younger adults in relation to lean body mass because it is an accepted fact that protein utilisation is less

* This paper has been given rapid publication on the recommendation of the Editorial Board.

$\uparrow$ For reprints. 
efficient in the elderly'. In fact as recently reviewed (Campbell \& Evans, 1996; Millward \& Roberts, 1996) there is remarkably little information on the protein requirements of the elderly, and in the studies that have been reported there is considerable variation in experimental design and consequent security of the findings. Indeed in their analysis of the $\mathrm{N}$ balance studies Millward \& Roberts (1996) concluded that there was no published study which could be described as ideal even within the limits of acceptability for $\mathbf{N}$ balances. Most importantly, we are not aware of any specific studies which have attempted to assess the efficiency of protein utilization in the elderly in a systematic way to verify the assumed age-related deterioration implied in the 1985 report (FAO/WHO/UNU, 1985). Given that overall $\mathrm{N}$ balance is achieved within a diurnal cycle of postabsorptive losses and postprandial gain (Price et al. 1994) the overall protein requirement for $\mathrm{N}$ homeostasis will be influenced by both the magnitude of postabsorptive losses, which generates the metabolic demand, and the efficiency of postprandial protein utilization to replete these losses (Millward \& Rivers, 1988; Millward \& Pacy, 1995). Thus, it is important in an investigation of protein requirements, to assess each of these components. For these reasons we have applied a novel stable-isotope $\left[{ }^{13} \mathrm{C}\right]$ amino acid balance technique to assess both metabolic demand from leucine oxidation in the postabsorptive state, and efficiency of utilization from leucine balance during feeding of frequent meals in a healthy group of elderly men and women in comparison with young adult control groups. Some of these results have been described in a preliminary form (Fereday et al. 1994).

\section{METHODS}

\section{Subjects}

Twenty subjects were studied, ten men and ten women, all in good general health and with normal renal and hepatic function. The elderly subjects were all mobile and recruited by personal contact or through the University of the Third Age. The young adults were recruited through personal contacts. No restriction was placed on activities of daily living but subjects were encouraged to regulate their eating pattern to one of $12 \mathrm{~h}$ feeding and $12 \mathrm{~h}$ fasting for the week before the study based on a 09.00 hours start. The study was approved by the local ethical committee and all subjects gave informed consent after the nature of the protocol had been fully explained to them.

Because the metabolic studies required feeding at levels which represented habitual protein intakes, estimates of these values were needed. Habitual dietary protein intake was calculated from three $24 \mathrm{~h}$ measurements of total urinary $\mathrm{N}$ excretion on the basis that subjects were in $\mathrm{N}$ equilibrium so that total $\mathrm{N}$ loss was the same as $\mathrm{N}$ intake. Total $\mathrm{N}$ excretion was estimated from measured urinary and estimated faecal and surface $\mathrm{N}$ losses on the basis that the diet had a $95 \%$ true digestibility (Food and Agriculture Organization/ World Health Organization, 1991) and that obligatory $N$ losses were 8 and $12 \mathrm{mg} \mathrm{N} / \mathrm{kg}$ for surface and faecal losses (FAO/WHO/UNU, 1985).

Timed $24 \mathrm{~h}$ urine collections were made for all subjects in pre-weighed plastic, lidded containers with $5 \mathrm{ml} 11 \mathrm{M}-\mathrm{HCl}$ as a preservative, and a sample of the urine was refrigerated $\left(4^{\circ}\right)$ until Kjeldahl analysis of $\mathrm{N}$ by a semi-automated Kjeldahl method (Tecator Kjeltec Auto 1030 Analyzer, Tecator, Hoganas, Sweden).

\section{Body composition}

The fat-free mass (FFM) was determined by underwater weighing, in all except four elderly subjects (two men and two women), and by bioelectrical impedance in all subjects. 
Underwater weighing was achieved in an in-house designed tank-strain gauge apparatus. Residual lung volume was measured directly in the subjects by rebreathing a fixed volume of pure $\mathrm{O}_{2}$ which was subsequently analysed for $\mathrm{O}_{2}$ and $\mathrm{CO}_{2}$ content using a Servomex 540A paramagnetic $\mathrm{O}_{2}$ analyser (Servomex Ltd, Crowborough, Sussex) and a 645A infrared absorption $\mathrm{CO}_{2}$ analyser (The Analytical Development Co. Ltd, Hoddesdon, Herts.), linked to a chart recorder. Underwater weight was recorded by a kymograph, body volume calculated taking into account residual lung volume, and the density of the body calculated from weight in air and volume. Finally the percentage body fat was estimated from density using Siri's equation (Siri, 1961).

Bioelectrical impedance was measured with a bi-polar, Bio-resistance Body Composition Analyzer (Valhalla Scientific model 1990B; Valhalla Scientific, San Diego, CA, USA) with percentage body fat indicated after entering height, weight and age. The values obtained by these two methods corresponded well as described in detail elsewhere (Pacy et al. 1995).

\section{Infusions}

The volunteers were asked to complete their last meal at 21.00 hours at home and report to the metabolic ward at 07.30 hours. Intravenous cannulas were inserted into superficial veins of both arms or hands, one allowing continuous infusion of the tracer, the other allowing repeated blood sampling. This was arterialized by the hot-box technique (Abumrad et al. 1981). After collection of baseline blood and expired breath samples (in duplicate) priming doses of $\mathrm{L}-\left[1-{ }^{13} \mathrm{C}\right]$ leucine (either 0.5 or $1 \mathrm{mg} / \mathrm{kg}$ ) and $\mathrm{NaH}^{13} \mathrm{CO}_{2}$ $(0.2 \mathrm{mg} / \mathrm{kg})$ were given. These were followed immediately by a continuous infusion of $\mathrm{L}-$ $\left[1-{ }^{13} \mathrm{C}\right]$ leucine (either 0.5 or $1 \mathrm{mg} / \mathrm{kg}$ per $\mathrm{h}$ ) for $9 \mathrm{~h}$ starting in most cases at 08.00 hours (11 h postabsorptive).

Blood and expired breath samples (in duplicate) were collected every $15 \mathrm{~min}$ throughout the last hour of each $3 \mathrm{~h}$ phase. Concentrations of cholesterol and triacylglycerols were measured at the end of each $3 \mathrm{~h}$ phase, glucose at the beginning and end of each $3 \mathrm{~h}$, insulin at 2 and $3 \mathrm{~h}$ of each $3 \mathrm{~h}$, and plasma $\alpha$-ketoisocaproic acid (KIC) ${ }^{13} \mathrm{C}$ enrichment, leucine concentration, and expired breath ${ }^{13} \mathrm{CO}_{2}$ enrichment were measured every $15 \mathrm{~min}$ during the last hour of each $3 \mathrm{~h}$. Total $\mathrm{CO}_{2}$ production and $\mathrm{O}_{2}$ consumption rates were measured for at least $60 \mathrm{~min}$ during each phase by an in-house indirect calorimeter and ventilated hood system.

\section{Meals}

During the feeding phase, subjects were given liquid-based meals to facilitate absorption and minimize problems of digestibility, every $30 \mathrm{~min}$ in order to maintain a metabolic steady state during each $3 \mathrm{~h}$ feeding phase. The meals were formulated from potato glucose (Avebe, Veendam, Holland), double cream, and either full-cream milk (low-protein (LP) diet) or skimmed milk (high-protein (HP) diet) (see Table 1). The LP and HP diets were individually formulated for each subject, to be isoenergetic, but to vary between subjects in order to provide overall energy intakes, and protein intakes in the HP phase, at an appropriate level for each subject (see Table 2). The protein intake provided, in the HP phase, an hourly intake equivalent of $1 / 12$ of the habitual intake established from the urinary $\mathrm{N}$ excretion. The energy intakes were set to provide an hourly intake equivalent to $1 / 12$ (i.e. $50 \%$ in total) of the subject's estimated daily maintenance energy requirements, calculated as 1.4 times resting metabolic rate (RMR). Given that the subjects were 
Table 1. Meal ingredient composition $(\mathrm{g} / \mathrm{kg})$

\begin{tabular}{|c|c|c|c|c|}
\hline Ingredient & Protein & Fat & Carbohydrate & Energy $(\mathrm{kJ} / \mathrm{kg})$ \\
\hline Double cream & 17 & 470 & 26 & 18370 \\
\hline Milk & 34 & 39 & 48 & 2800 \\
\hline Skimmed milk & 34 & 1 & 50 & 1420 \\
\hline Potato glucose & - & - & 1000 & 15650 \\
\hline
\end{tabular}

Table 2. Energy and protein variables for the experimental meals consumed by young female $(Y f)$, young male $(\mathrm{Ym})$, elderly female $(E f)$ and elderly male $(\mathrm{Em})$ subjects

(Mean values and standard deviations)

\begin{tabular}{|c|c|c|c|c|c|c|}
\hline \multirow[b]{3}{*}{ Subjects } & \multirow{2}{*}{\multicolumn{2}{|c|}{$\begin{array}{l}\text { Energy intake } \\
(\mathrm{kJ} / \mathrm{kg} \text { per } 6 \mathrm{~h})\end{array}$}} & \multicolumn{4}{|c|}{ Protein : energy ratio (\%) } \\
\hline & & & \multicolumn{2}{|c|}{ Low protein } & \multicolumn{2}{|c|}{ High protein } \\
\hline & Mean & $\overline{S D}$ & Mean & $\overrightarrow{\text { SD }}$ & Mean & SD \\
\hline Yf & 79.0 & 9.1 & 2.2 & 0.1 & 13.6 & 0.6 \\
\hline $\mathrm{Ym}$ & 76.5 & 4.2 & 2.2 & 0.2 & 12.2 & 1.9 \\
\hline Ef & 57.5 & 5.4 & 3.0 & 0.4 & 18.0 & 1.9 \\
\hline Em & 55.5 & 6.1 & 2.9 & 0.2 & 15.9 & 2.5 \\
\hline All & $67 \cdot 1$ & 6.2 & 2.6 & 0.2 & 14.9 & 1.7 \\
\hline
\end{tabular}

physically inactive during the infusion their actual energy expenditure was low: measured values indicated an overall level of 1.08 times RMR in the young and 1.07 times RMR in the elderly during the $9 \mathrm{~h}$. The carbohydrate content (a low naturally ${ }^{13} \mathrm{C}$-enriched potato glucose) was fixed at $60 \%$ of energy and low food ${ }^{13} \mathrm{C}$ enrichment was confirmed in four individuals who underwent a 'food only' study during other investigations involving a diet identical to that used here (Gibson et al. 1996). Dietary fat and protein were exchanged isoenergetically in the LP and HP formulations, and accounted for 37 and $2.6 \%$ of the energy respectively in the LP diet and 25 and $14.9 \%$ respectively in the HP diet. The lower energy intakes of elderly men and women resulted in higher protein : energy $(P: E)$ ratios for these subjects. Samples of each diet were analysed for total $\mathrm{N}$ by the Kjeldahl method and the leucine $: \mathrm{N}$ ratio of the milk protein was determined by gas chromatography-mass spectrometry (GC-MS) analysis of an acid-hydrolysed milk sample for leucine and Kjeldahl analysis for $\mathrm{N}$. This indicated a leucine content of the diet of $4.46 \mu \mathrm{mol}$ leucine/ mg food $\mathrm{N}$.

\section{Isotopes}

$\mathrm{L}-\left[1-{ }^{13} \mathrm{C}\right]$ leucine $\left(99 \%{ }^{13} \mathrm{C}\right.$ ) and $\mathrm{NaH}^{13} \mathrm{CO}_{2}\left(99 \%{ }^{13} \mathrm{C}\right.$ ) (Cambridge Isotope Laboratories, Woburn, MA, USA) were packaged into sterile and pyrogen-free $10 \mathrm{ml}$ ampoules (10 mg/ $\mathrm{ml}$ in $150 \mathrm{mM}-\mathrm{NaCl}$ ) by a dispensing pharmacy.

\section{Assays}

Blood samples were centrifuged immediately and plasma stored at $-70^{\circ}$. For blood glucose, blood was transferred to fluoride oxalate-containing tubes and glucose measured by a standard automated hexokinase (EC 2.7.1.1) technique. Cholesterol and triacylglycerol were measured by a standard cholesterol oxidase (EC 1.1.3.6) method and a standard 
Kodak dry-slide technique for triacylglycerol. Plasma insulin was measured using a double antibody, PEG dual-incubation assay with ${ }^{125}$ I-labelled insulin, and with a monoclonal anti-insulin (donkey anti-guinea-pig) antiserum as the second antiserum.

\section{Plasma $\alpha$-ketoisocaproic acid enrichment and leucine concentration measurement}

The ${ }^{13} \mathrm{C}$ enrichment of $\mathrm{KIC}$ was measured as its trimethylsilyl derivative with ketovaleric acid (10 ng) acting as an internal standard, on a MD800 (Fisons Instruments Manchester, Greater Manchester) GC-MS monitoring $\mathrm{m} / \mathrm{z} 232.1$ and 233.1 under electron impact ionization conditions. Plasma leucine was derivatized to its tertiary butyldimethylsilyl derivative monitoring $\mathrm{m} / \mathrm{z} 302.2$ and 303.2 . All values were corrected for the respective calibration curves.

\section{Expired breath ${ }^{13} \mathrm{CO}_{2}$ enrichment}

Expired breath samples were collected in a 2 litre latex bag, transferred into $20 \mathrm{ml}$ vacutainers (Becton Dickinson Vacutainer Systems Europe, Cowley, Oxon) and the ${ }^{13} \mathrm{C}$ enrichment in the expired $\mathrm{CO}_{2}$ was measured on a dual inlet double collector isotope-ratio mass spectrometer (Finnigan Delta S, Manchester, Greater Manchester) or on a Europa Roboprep G (Europa, Crewe, Ches.) and 20/20 triple collector isotope-ratio mass spectrometer.

\section{Leucine oxidation}

Leucine oxidation was calculated as $\mu \mathrm{mol} / \mathrm{kg}$ per $\mathrm{h}$ as described previously (Waterlow et al. 1978; Price et al. 1994) from rates of ${ }^{13} \mathrm{CO}_{2}$ excretion and plasma KIC enrichment, assuming $\left[{ }^{13} \mathrm{C}\right]$ bicarbonate recovery values of 0.76 (fasted) and 0.91 (fed), as reported previously (Wenham et al. 1991).

\section{Postprandial protein utilization, metabolic demand and protein requirements}

The calculation of the efficiency of postprandial protein utilization (PPU), metabolic demand and protein requirements is based on experimental findings of Price et al. (1994) and Quevedo et al. (1994) as discussed by Millward \& Pacy (1995). The fate of dietary protein is viewed as a partition between provision for metabolic demands and any amino acid oxidation associated with any inefficiency of utilization. The metabolic demand comprises three components: (1) postprandial protein deposition which repletes postabsorptive losses; (2) postprandial oxidative losses which are adaptive according to the habitual diet; and (3) the obligatory losses which result from irreversible transformation of some amino acids into useful metabolites. Postabsorptive losses comprise both the obligatory losses and the adaptive component.

On this basis oxidative losses are divided into three components, i.e.

$\mathrm{L}_{\mathrm{o}}$, fixed obligatory endogenous losses through amino acid metabolic consumption;

$L_{\mathrm{rl}}$, variable endogenous regulatory oxidative losses at rates reflecting only previous protein intakes;

$\mathrm{L}_{\mathrm{r} 2}$, regulatory oxidative losses reflecting only any inefficiency of meal protein utilization. 
At balance, postprandial protein deposition, $G_{t}$ repletes all postabsorptive losses: i.e.

$$
\mathrm{G}_{\mathrm{t}}=\mathrm{L}_{\text {opostabsorptive }}+\mathrm{L}_{\mathrm{rl} \text { postabsorptive }}
$$

and the metabolic demand is to provide for $G_{t}$ and the first two components of oxidative losses: i.e.

$$
\text { metabolic demand }=\mathrm{G}_{\mathrm{t}}+\mathrm{L}_{\mathrm{opossprandial}}+\mathrm{L}_{\mathrm{rl} \text { postprandial }} \text {. }
$$

Assuming that $\mathrm{L}_{\mathrm{o}}$ and $\mathrm{L}_{\mathrm{T} 1}$ occur at similar rates throughout postabsorptive and postprandial phases of the diurnal cycle (i.e. $\mathrm{L}_{\mathrm{o}}$ postprandial $+\mathrm{L}_{\mathrm{r} 1}$ postprandial $=\mathrm{L}_{\mathrm{o}}$ postabsorptive

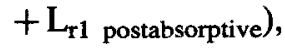

$$
\text { metabolic demand }=2 \mathrm{G}_{\mathrm{t}}=2 \times \text { total postabsorptive losses. }
$$

With the leucine content of tissue protein as $3.93 \mu \mathrm{mol} / \mathrm{mg} \mathrm{N}$ (see Price et al. 1994) the protein equivalent of postabsorptive leucine oxidation is $0.629 \mathrm{mmol} / \mathrm{g}$ protein. The protein requirement $(R)$ is the intake required to satisfy the metabolic demand and for efficiencies of $<100 \%$ will exceed the metabolic demand by an amount equal to $L_{r 2}$ i.e.

$$
\mathrm{R}=2 \mathrm{G}_{\mathrm{t}}+\mathrm{L}_{\mathrm{r} 2} \text {. }
$$

PPU is defined as the ratio of metabolic demand and the requirement, i.e.

$$
P P U=2 G_{t} /\left(2 G_{t}+L_{r 2}\right)
$$

therefore

$$
R=2 G_{t} / P P U .
$$

On the basis that the fate of leucine indicates the fate of amino acids in general and that $\left[1-{ }^{13} \mathrm{C}\right]$ leucine is a valid tracer for leucine metabolism, PPU can be calculated during the current protocol from the slope of the leucine intake-balance curve (change in leucine balance/change in leucine intake) in two ways. The slope calculated from postabsorptive to HP balance represents the influence of the entire meal (i.e. both energy and protein) on

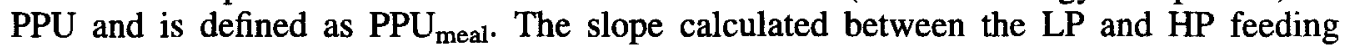
periods involves changes in leucine balance at constant energy intake representing only the

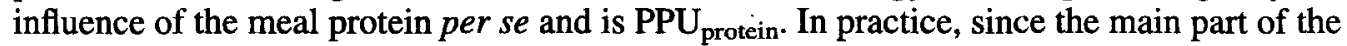
change in leucine balance occurs during the LP to HP transition, PPU $U_{\text {meal }}$ will not be

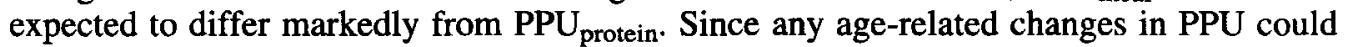
involve responses to both energy (e.g. insulin) and protein (i.e. amino acids) the protein requirement is best calculated from $P_{P U_{m e a l}}$ whilst $P P U_{\text {protein }}$ is most appropriate as a descriptor of protein quality which is largely independent of energy level.

\section{Statistical analysis}

Values are expressed as means $\pm 1 \mathrm{SD}$. We used the Statistica package (Statsoft, Letchworth, Herts.) and examined the influence of age and of dietary period on the various variables by a one-way ANOVA after testing for normality of distribution by the Shapiro-Wilks' W test. Where normality was not observed the Kruskal-Wallis ANOVA by Ranks test was applied. With the four groups, young and old, men and women as classification factors, an ANOVA run for the four groups would identify differences which could be due to either age or sex. For this reason age effects were examined by ANOVA for (a) young and old $(2 \times 10$ subjects), (b) young and old men $(2 \times 5$ subjects $)$ and (c) young and old women $(2 \times 5$ subjects $)$. This resulted in identification of age effects within 
each sex which were not always apparent for both sexes combined (e.g. percentage body fat) and age effects within both sexes combined which were not always apparent within either sex alone (e.g. LP oxidation rates). Thus, in the tables, significant age effects are indicated for the entire group and both sexes separately. Sex effects were identified by ANOVA for all men and women $(2 \times 10$ subjects). In some cases Pearson correlation coefficients were calculated to identify any linear relationships. Significance was set at $5 \%$ but for those values close to $5 \%$ the actual $P$ values are also quoted.

\section{RESULTS}

Table 3 shows the statistics for the four subject groups studied, young and elderly men and women. There was no difference in the body weights (BW) or FFM between the young and elderly subjects. However the elderly women had a higher percentage body fat than the young women $(P=0.03)$. Also, compared with the men, the women were lighter, $(P=0.001)$, shorter, $(P=0.006)$, had less FFM $(P=0.001)$, and higher percentage fat $(P=0.01)$. The RMR was lower in the elderly men $(P=0.001)$ and women $(P=0.023)$ on a BW basis but RMR/kg FFM was only lowered by age in the men $(P=0.018)$. Whilst mean values for RMR/kg FFM were higher in women compared with men this was not significant $(P=0 \cdot 149)$. Estimated protein intakes (Table 4) were lower in women compared with men $(P=0.02)$ but were the same in all groups when calculated on a FFM basis.

\section{Hormonal and biochemical responses}

The plasma insulin and leucine values will be presented and discussed in a subsequent paper. Plasma glucose increased during both fed periods although it was lower during the HP compared with the LP period (results not shown). These responses were not influenced by either age or sex. Plasma cholesterol levels were generally constant throughout the three phases of the study (results not shown). Values were higher in elderly women (6.54 (SD $0.88) \mathrm{mmol} / 1$ compared with an overall group mean of 4.5 (SD 2) $\mathrm{mmol} / \mathrm{l}, P=0.005$ ). Postabsorptive TAG levels did not vary between groups (results not shown) but

Table 3. Characteristics of young female (Yf), young male ( $\mathrm{Ym})$, elderly female (Ef) and elderly male $(E m)$ subjects

(Mean values and standard deviations)

\begin{tabular}{|c|c|c|c|c|c|c|c|c|c|c|c|c|c|c|c|}
\hline \multirow[b]{3}{*}{ Subjects } & \multirow[b]{3}{*}{$n$} & \multirow{2}{*}{\multicolumn{2}{|c|}{$\begin{array}{c}\text { Age } \\
\text { (years) }\end{array}$}} & \multirow{2}{*}{\multicolumn{2}{|c|}{$\begin{array}{l}\text { Weight } \\
\text { (kg) }\end{array}$}} & \multirow{2}{*}{\multicolumn{2}{|c|}{$\begin{array}{l}\text { Height } \\
\text { (m) }\end{array}$}} & \multirow{2}{*}{\multicolumn{2}{|c|}{$\begin{array}{l}\text { FFM } \\
(\mathrm{kg})\end{array}$}} & \multirow{2}{*}{\multicolumn{2}{|c|}{$\begin{array}{c}\text { Fat } \\
\text { (\% body wt) }\end{array}$}} & \multicolumn{4}{|c|}{ Resting metabolic rate } \\
\hline & & & & & & & & & & & & $(\mathrm{kJ} / \mathrm{kg}$ & (r) & $(\mathrm{kJ} / \mathrm{kg} \mathrm{F}$ & per $d$ ) \\
\hline & & Mean & SD & Mean & $\mathrm{SD}$ & Mean & SD & Mean & SD & Mean & SD & Mean & SD & Mean & SD \\
\hline Yf & 5 & $26 \cdot 0$ & 3.8 & 56.9 & $2 \cdot 2$ & 1.70 & 0.05 & $47 \cdot 1$ & $4 \cdot 1$ & $17 \cdot 3$ & 4.5 & 110 & 17 & 132 & 26 \\
\hline Ym & 5 & 21.4 & 1.4 & 67.3 & 3.1 & 1.76 & 0.04 & $58 \cdot 6$ & 2.6 & 13.0 & $3 \cdot 3$ & 105 & 12 & 120 & 9 \\
\hline Ef & 5 & $72 \cdot 0^{3}$ & 4.6 & 61.4 & 6.2 & 1.59 & 0.08 & 45.4 & 5.0 & $26.0^{a}$ & $4 \cdot 0$ & $82^{a}$ & 8 & 111 & 9 \\
\hline $\mathrm{Em}$ & 5 & $77 \cdot 6^{a}$ & $8 \cdot 1$ & 71.4 & 7.7 & 1.72 & 0.03 & 59.4 & 5.7 & 16.6 & 5.2 & $82^{a}$ & 5 & $98^{\mathrm{a}}$ & 14 \\
\hline All & 20 & $49 \cdot 3^{\mathrm{a}}$ & $26 \cdot 2$ & $64 \cdot 2^{\text {s }}$ & 7.7 & $1.69^{s}$ & 0.08 & $52.8^{\mathrm{s}}$ & $7 \cdot 8$ & $17 \cdot 9^{s}$ & 6.7 & $95^{\mathrm{a}}$ & 12 & $115^{\mathrm{a}}$ & 16 \\
\hline
\end{tabular}

FFM, fat-free mass.

${ }^{a}$ The effect of age was significant, $P<0.05$ (ANOVA).

$s$ The effect of sex was significant, $P<0.05$ (ANOVA). 
Table 4. Estimated protein intakes for young female (Yf), young male (Ym), elderly female (Ef) and elderly male (Em) subjects

(Mean values and standard deviations)

\begin{tabular}{|c|c|c|c|c|c|}
\hline \multirow[b]{3}{*}{ Subjects } & \multirow[b]{3}{*}{$n$} & \multicolumn{4}{|c|}{ Estimated protein intake } \\
\hline & & \multicolumn{2}{|c|}{ (g/kg per d) } & \multicolumn{2}{|c|}{ (g/kg FFM per d) } \\
\hline & & Mean & $\overline{\mathrm{SD}}$ & Mean & $\overline{\mathrm{SD}}$ \\
\hline $\mathrm{Yf}$ & 5 & 1.14 & 0.09 & 1.38 & 0.16 \\
\hline $\mathrm{Ym}$ & 5 & 1.24 & 0.05 & 1.43 & 0.10 \\
\hline Ef & 5 & 1.06 & 0.15 & 1.43 & 0.15 \\
\hline $\mathrm{Em}$ & 5 & $1 \cdot 18$ & 0.04 & 1.40 & 0.14 \\
\hline All & 20 & $1.16^{\mathrm{s}}$ & 0.08 & 1.41 & 0.12 \\
\hline
\end{tabular}

FFM, fat-free mass.

s The effect of sex was significant, $P<0.05$ (ANOVA).

postprandial levels were also higher in the elderly women in both LP (1.90 (SD 0.99) mmol/ 1 compared with 1.01 (SD 1.1 ) mmol/l group mean, $P=0.032$ ) and HP periods (2.28 (SD 1.03 ) $\mathrm{mmol} / \mathrm{l}$ compared with 1.31 (SD 1.1$) \mathrm{mmol} / \mathrm{l}$ group mean, $P=0.021$ ).

The enrichments of leucine, $\mathrm{KIC}$ and $\mathrm{CO}_{2}$ for the last hour of each phase are shown in Fig. 1 as mean values for all subjects. Plateau values were observed in all subjects although the most variability was observed in the case of leucine. Leucine and KIC enrichment increased with LP feeding $(P<0.001)$ and fell with HP feeding $(P<0.001)$. Mean KIC : leucine enrichment values were $0.78,0.77$ and 0.80 in the postabsorptive, LP and HP periods respectively. $\mathrm{CO}_{2}$ enrichment remained largely unchanged with LP feeding and increased slightly with HP feeding. The age and sex effects in these values are discussed in relation to the derived kinetic parameters.

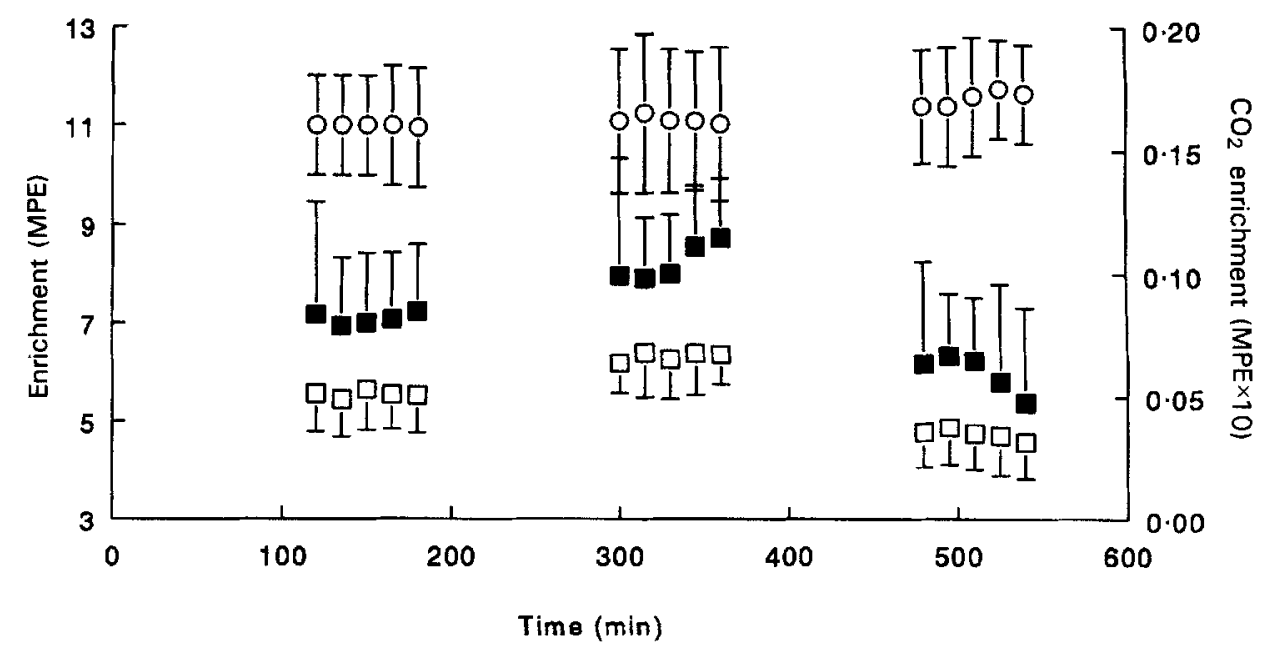

Fig. $1 .{ }^{13} \mathrm{C}$-enrichments (mol \% enrichment, MPE) of leucine ( $\square$ ), $\alpha$-ketoisocaproate (KIC, $\square$ ) and carbon dioxide (O) during the last hour of each of three phases of $\left[{ }^{13} \mathrm{C}\right]$ leucine infusion. For details of subjects and procedures, see pp. 686689. Values are means for twenty subjects, with standard deviations represented by vertical bars. 


\section{Leucine oxidation and balance}

Table 5 shows the leucine intake, oxidation and consequent balance values. Intakes include tracer at levels shown by postabsorptive values. Since the LP intakes were calculated to be the same per $\mathrm{kg} \mathrm{BW}$, with the lower FFM in the women, intakes were slightly higher per kg FFM in the women compared with men $(P=0.044)$. The intake in the HP phase was designed to reflect habitual protein intake and this was higher in the men compared with women $(P=0.015)$, but intakes per $\mathrm{kg}$ FFM were not different between groups.

Postabsorptive leucine oxidation was lower in both elderly men $(P=0.006)$ and women $(P=0.014)$ per kg BW and lower per kg FFM in the men $(P=0.02)$ but not in the women $(P=0.09)$. With LP feeding leucine oxidation remained unchanged and whilst there was a significant age effect $(P=0.007)$ with lower mean values in both men and women, in neither case were they significant $(P=0.058 \mathrm{men}$ and 0.10 women). When calculated per $\mathrm{kg}$ FFM there were no differences between groups. With HP feeding oxidation increased in all groups $(P<0.0001)$. There were no age or sex effects per $\mathrm{kg}$ $\mathrm{BW}$, but leucine oxidation was marginally higher in women per $\mathrm{kg}$ FFM $(P=0.057)$.

Leucine balance became less negative $(P<0.0001)$ with $L P$ feeding and positive $(P<0.0001)$ with HP feeding. Leucine balance in the postabsorptive state was lower in both elderly men $(P=0.008)$ and women $(P=0.013)$ per $\mathrm{kg} \mathrm{BW}$, and per $\mathrm{kg}$ FFM $(P=0.013$, men; $P=0.050$ women $)$. With LP feeding whilst there was a significant age effect on leucine balance $(P=0.008)$ with lower mean values in both men and women, in neither case were they significant $(P=0.066 \mathrm{men}$ and 0.11 women) with no overall significance in the differences between the groups $(P=0.09)$. This pattern of differences was also observed for leucine balance calculated per kg FFM. With HP feeding leucine

Table 5. Leucine intake, oxidation and balance in young female (Yf), young male (Ym), elderly female (Ef) and elderly male (Em) subjects during low-protein (LP), high-protein (HP) and postabsorptive (PA) periods

(Mean values and standard deviations for five subjects per age-sex group)

\begin{tabular}{|c|c|c|c|c|c|c|c|c|c|c|c|c|c|}
\hline \multirow[b]{3}{*}{ Subjects } & \multirow[b]{3}{*}{ Period } & \multicolumn{6}{|c|}{$\mu \mathrm{mol}$ leucine $/ \mathrm{kg}$ per $\mathrm{h}$} & \multicolumn{6}{|c|}{$\mu \mathrm{mol}$ leucine/kg FFM per $\mathrm{h}$} \\
\hline & & \multicolumn{2}{|c|}{ Intake } & \multicolumn{2}{|c|}{ Oxidation } & \multicolumn{2}{|c|}{ Balance } & \multicolumn{2}{|c|}{ Intake } & \multicolumn{2}{|c|}{ Oxidation } & \multicolumn{2}{|c|}{ Balance } \\
\hline & & Mean & SD & Mean & SD & Mean & SD & Mean & SD & Mean & SD & Mean & SD \\
\hline \multirow[t]{3}{*}{ Yf } & PA & 6.9 & 0.5 & 28.6 & 3.6 & -21.7 & 3.6 & 8.4 & 1.0 & 34.8 & $5 \cdot 3$ & -26.4 & 4.9 \\
\hline & LP & 19.9 & 0.5 & $27 \cdot 7$ & 3.3 & -7.8 & $3 \cdot 5$ & $24 \cdot 2$ & 1.8 & 33.6 & $4 \cdot 3$ & -9.4 & $4 \cdot 1$ \\
\hline & HP & 81.0 & $4 \cdot 7$ & $40 \cdot 0$ & $5 \cdot 5$ & $41 \cdot 1$ & 6.4 & $98 \cdot 0$ & 2.4 & 48.5 & 7.2 & 49.6 & $6 \cdot 7$ \\
\hline \multirow[t]{3}{*}{ Ym } & PA & 7.2 & 0.1 & 30.7 & 1.5 & -23.5 & 1.5 & $8 \cdot 3$ & 0.4 & 35.3 & 2.8 & -27.1 & 2.5 \\
\hline & LP & $20 \cdot 2$ & $0 \cdot 1$ & $27 \cdot 6$ & $4 \cdot 5$ & $-7 \cdot 4$ & 4.0 & $23 \cdot 2$ & 0.9 & 31.8 & 5.7 & $-8 \cdot 6$ & 4.9 \\
\hline & $\mathrm{HP}$ & 87.8 & $3 \cdot 2$ & 38.4 & $3 \cdot 6$ & 49.5 & $4 \cdot 2$ & 100.9 & $2 \cdot 2$ & $44 \cdot 1$ & 4.0 & 56.8 & $4 \cdot 1$ \\
\hline \multirow[t]{3}{*}{ Ef } & PA & 6.8 & 0.1 & $20 \cdot 5^{a}$ & 3.7 & $-13.7^{a}$ & 3.7 & 9.3 & 0.5 & 27.8 & $5 \cdot 0$ & $-18 \cdot 5^{\mathrm{a}}$ & 4.8 \\
\hline & LP & 19.8 & 0.1 & $22 \cdot 6$ & $4 \cdot 3$ & -2.8 & $4 \cdot 3$ & 26.9 & 1.4 & 30.8 & 6.5 & -3.9 & 5.8 \\
\hline & HP & $77 \cdot 1$ & 7.6 & 36.7 & 8.6 & 40.4 & 14.7 & 104.5 & 1.2 & 49.5 & 10.9 & 54.9 & $20 \cdot 2$ \\
\hline \multirow[t]{3}{*}{ Em } & PA & 7.0 & 0.4 & $22 \cdot 2^{\mathrm{a}}$ & $4 \cdot 3$ & $-15 \cdot 2^{a}$ & $4 \cdot 6$ & $8 \cdot 3$ & 0.9 & $26 \cdot 3^{a}$ & $5 \cdot 2$ & $-18 \cdot 1^{\mathbf{a}}$ & 5.0 \\
\hline & LP & 20.0 & 0.4 & 22.0 & 3.0 & -2.0 & $3 \cdot 1$ & 23.8 & 1.9 & $26 \cdot 2$ & 4.6 & -2.5 & 3.6 \\
\hline & HP & 83.8 & 2.9 & 31.6 & $6 \cdot 1$ & $52 \cdot 2$ & 8.0 & 99.5 & 9.3 & 37.6 & 8.9 & 61.9 & 9.8 \\
\hline \multirow[t]{3}{*}{ All } & PA & 7.0 & 0.3 & $25 \cdot 5^{\mathrm{a}}$ & 5.5 & $-18 \cdot 5^{a}$ & 5.5 & 8.6 & 0.8 & $31 \cdot 0^{\mathrm{a}}$ & $6 \cdot 2$ & $-22 \cdot 5^{a}$ & $6 \cdot 1$ \\
\hline & LP & 20.0 & 0.3 & $25 \cdot 0^{\mathrm{a}}$ & $4 \cdot 6$ & $-5 \cdot 0^{a}$ & 4.6 & 24.5 & $2 \cdot 1$ & 30.6 & 6.0 & $-6 \cdot 1$ & 5.5 \\
\hline & $\mathrm{HP}$ & $82 \cdot 4^{5}$ & 6.3 & $36 \cdot 6$ & $7 \cdot 0$ & $45.8^{s}$ & $10 \cdot 5$ & 100.7 & 7.8 & $44 \cdot 9^{s}$ & 9.4 & 55.8 & 12.7 \\
\hline
\end{tabular}

FFM, fat-free mass.

${ }^{a}$ The effect of age was significant, $P<0.05$ (ANOVA).

s The effect of sex was significant, $P<0.05$ (ANOVA). 
balance was lower in women compared with men per $\mathrm{kg}(P=0.032)$, but not per $\mathrm{kg}$ FFM. There was no age effect on leucine balance in the HP period.

The balance curves for the four groups are shown in Fig. 2 and the slopes calculated between postabsorptive and HP and LP and HP periods are shown as PPU meal and $P U_{\text {protein }}$ in Table 6. It is clear that the main feature of the balance curves is a higher elevation for the elderly groups due to the significantly less negative postabsorptive and LP balances. Thus there were no overall significant differences between the groups for $\mathrm{PPU}_{\text {protein }}$ or $\mathrm{PPU}_{\text {meal }}$ although values for $\operatorname{PPU}_{\text {meal }}$ were lower for women $(P=0.037)$.

The implications of these balance curves for metabolic demands and estimated protein requirements are shown in Table 6. Metabolic demand calculated from the postabsorptive losses was reduced either per $\mathrm{kg} \mathrm{BW}$ (36\% reduction, $P<0.001)$ or per $\mathrm{kg} \mathrm{FFM} \mathrm{(30 \% ,}$ $P<0.001)$ in both elderly groups. The apparent protein requirement calculated from metabolic demand and PPU meal was also lower in the elderly although this was only significant in the men $(P=0.013$ per $\mathrm{kg} \mathrm{BW}, P=0.02$ per $\mathrm{kg}$ FFM). The individual values for the apparent protein requirements in relation to age are shown in Fig. 3.

\section{DISCUSSION}

The measurements reported here were performed in the context of concern for the adequacy of current dietary guidelines for protein for the elderly. Although the $1985 \mathrm{FAO} /$ WHO/UNU Expert Consultation concluded that the dietary protein requirement of healthy elderly people did not differ per $\mathrm{kg} \mathrm{BW}$ from that of younger adults, it is widely assumed that there may be a reduced efficiency of protein utilization (FAO/WHO/UNU, 1985). Also recent reports have suggested that protein requirements of the elderly are higher than in younger adults (see Campbell et al. 1994; Campbell \& Evans, 1996). N balance studies require careful design in order that their interpretation is relatively unambiguous (Millward et al. 1989) and because of the constraints in making measurements on this population

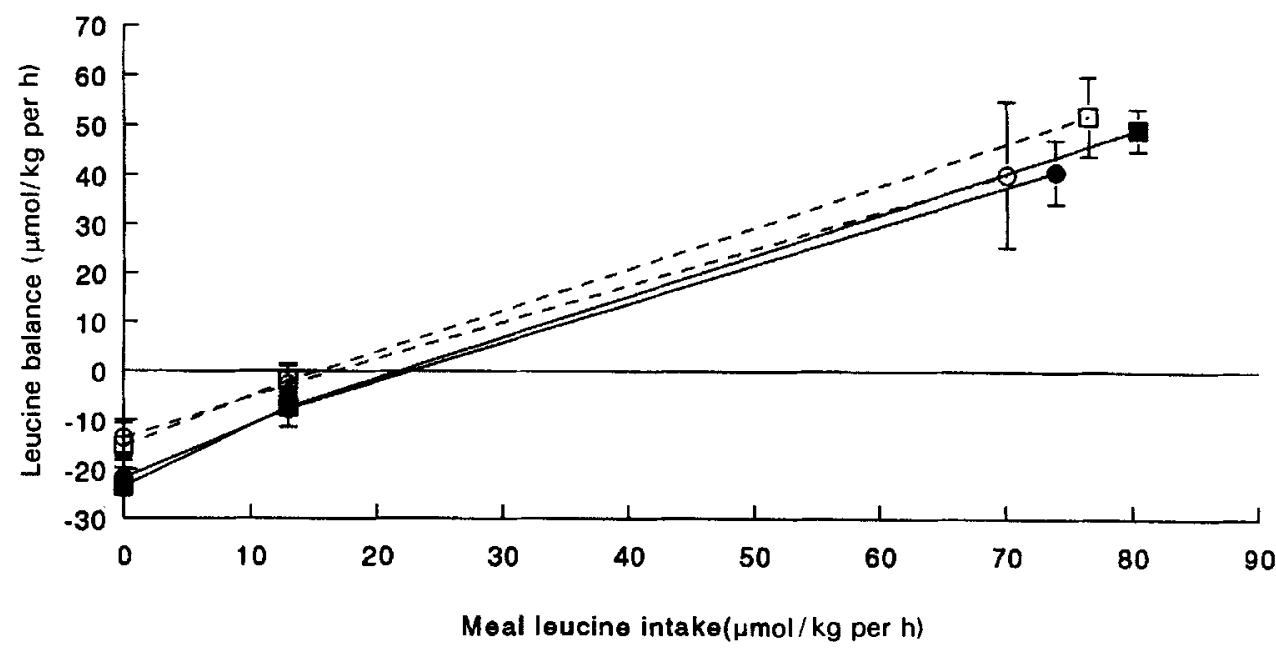

Fig. 2. Leucine balance curves for young female $(--)$, young male $(--)$, elderly female $\left(-\mathrm{O}_{-}\right)$, and elderly male $(-\square-)$ subjects. For details of procedures, see pp. 686-689. Values are means for five subjects, with standard deviations represented by vertical bars. Intake values are for meal leucine and exclude the leucine tracer. 
Table 6. Efficiency of postprandial protein utilization (PPU) and apparent protein requirement in young female (Yf), young male (Ym), elderly female (Ef) and elderly male (Em) subjects

(Mean values and standard deviations for five subjects per age-sex group)

\begin{tabular}{|c|c|c|c|c|c|c|c|c|c|c|c|c|}
\hline \multirow[b]{3}{*}{ Subjects } & & & & & \multicolumn{4}{|c|}{ Metabolic demand } & \multicolumn{4}{|c|}{ Apparent protein requirement } \\
\hline & \multicolumn{2}{|c|}{ PPU $_{\text {protein }}{ }^{*}$} & \multicolumn{2}{|c|}{$\mathrm{PPU}_{\text {meal }}{ }^{*}$} & \multicolumn{2}{|c|}{ (g/d per $\mathrm{kg}$ ) } & \multicolumn{2}{|c|}{ (g/d per kg FFM) } & \multicolumn{2}{|c|}{ ( $\mathrm{g} / \mathrm{d}$ per $\mathrm{kg})$} & \multicolumn{2}{|c|}{ (g/d per kg FFM) } \\
\hline & Mean & SD & Mean & SD & Mean & SD & Mean & SD & Mean & SD & Mean & $\overline{S D}$ \\
\hline Yf & 0.80 & 0.06 & 0.85 & 0.04 & 0.83 & 0.15 & 1.01 & 0.21 & 0.98 & 0.21 & $1 \cdot 20$ & 0.27 \\
\hline $\mathrm{Ym}$ & 0.84 & 0.08 & 0.91 & 0.04 & 0.90 & 0.06 & 1.03 & 0.11 & 0.99 & 0.09 & $1 \cdot 14$ & 0.12 \\
\hline Ef & 0.74 & 0.13 & 0.76 & 0.12 & $0.52^{\mathrm{a}}$ & $0 \cdot 16$ & $0.71^{a}$ & 0.21 & 0.71 & 0.28 & 0.96 & 0.35 \\
\hline Em & 0.85 & 0.11 & 0.88 & 0.08 & $0.58^{\mathrm{a}}$ & 0.19 & $0.60^{\mathrm{a}}$ & 0.21 & $0.66^{\mathrm{a}}$ & 0.21 & $0.79^{\mathrm{a}}$ & 0.24 \\
\hline All & 0.81 & 0.12 & $0.84^{\mathrm{s}}$ & 0.10 & $0.71^{\mathrm{a}}$ & 0.20 & $0.86^{\mathrm{a}}$ & 0.23 & $0.84^{\mathrm{a}}$ & 0.25 & $1.02^{\mathrm{a}}$ & 0.29 \\
\hline
\end{tabular}

FFM, fat-free mass.

a The effect of age was significant, $P<0.05$ (ANOVA).

s The effect of sex was significant, $P<0.05$ (ANOVA).

* For an explanation, see pp. $690-691$.

group no published studies can be classed as entirely satisfactory. For this reason differences in opinion exist in the interpretation of the published $\mathrm{N}$ balance studies. Indeed Millward \& Roberts (1996) have argued that there is as yet no unequivocal evidence for a revision of the $1985 \mathrm{FAO} / \mathrm{WHO} / \mathrm{UNU}$ conclusion.

\section{The metabolic model}

The present studies need to be evaluated in the context of the model for protein requirements originally proposed by Millward \& Rivers (1988) and further developed by Millward \& Pacy (1995). The main feature of this model is that of an adaptive metabolic demand for protein which is variable according to the habitual level of protein intake. This in turn sets a rate of amino acid oxidation in both postabsorptive and postprandial states (Price et al. 1994) which will occur regardless of the acute intake level (Quevedo et al. 1994). On this basis it is assumed that (a) normal healthy subjects can adapt to and achieve $\mathrm{N}$ equilibrium over a wide range of protein intakes, given sufficient time and adequate intakes of energy and other nutrients, and (b) minimal protein requirements can only be established by long-term studies in subjects receiving intakes considerably below those observed in physically active adults receiving otherwise nutritionally replete mixed diets. Thus, the present studies were not designed to assess a minimum protein requirement and define any influence of age. Rather we have examined the characteristics of $\mathbf{N}$ homeostasis in young and elderly subjects with similar habitual protein intakes, to identify any differences which might allow insight into the nutritional needs of the elderly. Specifically we have examined the efficiency of PPU directly, as well as the metabolic demand generated by the habitual intakes of our subjects which together indicate the apparent protein requirements of the subjects. The results indicate a reduced metabolic demand in both elderly men and women per $\mathrm{kg} \mathrm{BW}$ or per $\mathrm{kg}$ FFM, values for PPU which are on average lower but not significantly so, and apparent protein requirements per kg FFM which are on average lower in both elderly women and men, significantly so in the latter case. Thus, our results do not support the need to increase protein requirements in the healthy elderly compared with younger adults. 


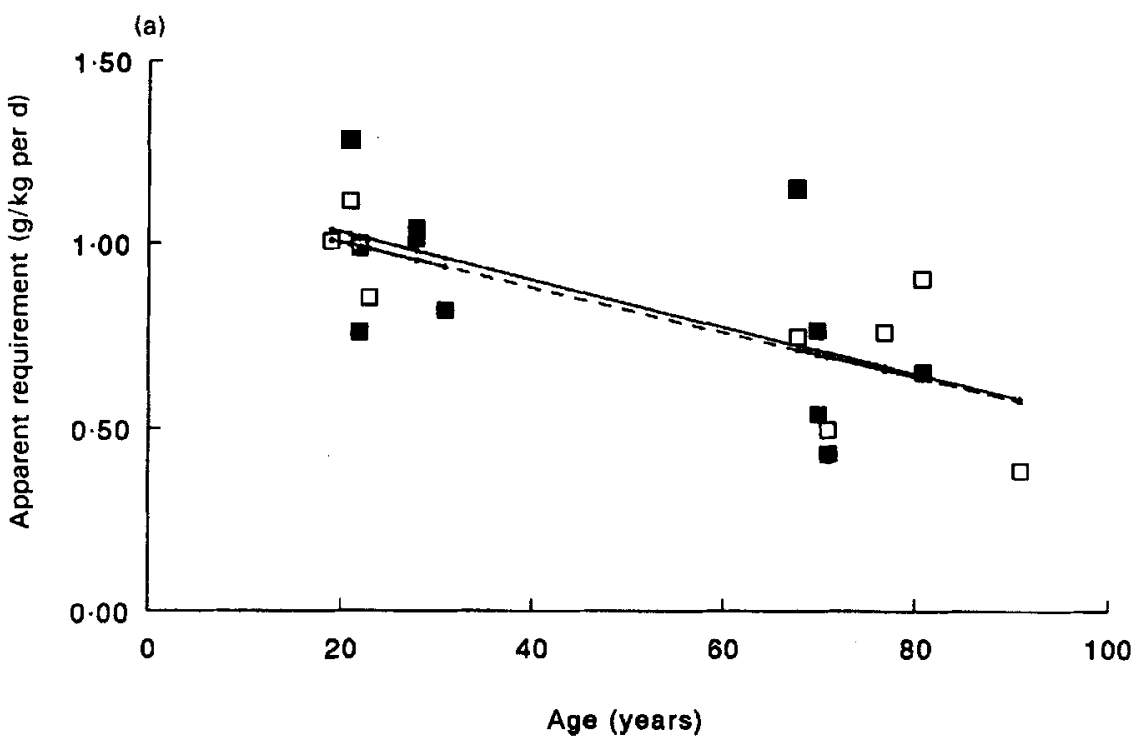

(b)

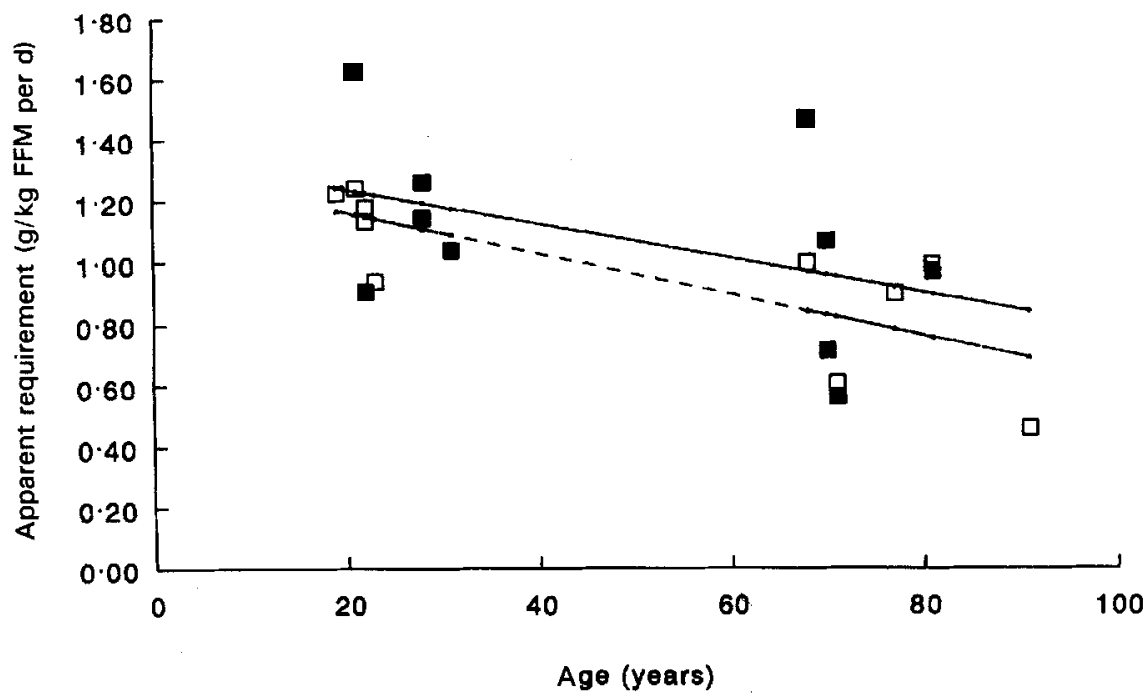

Fig. 3. Individual values for the apparent protein requirements expressed as (a) $\mathrm{g} / \mathrm{kg}$ body weight per $\mathrm{d}$ and (b) $\mathrm{g} / \mathrm{kg}$ fatfree mass (FFM) per $d$ in relation to age. (U), females; ( $\square$ ), males; (-), regression line for females; (- - -), regression line for males. Panel (a): females, $r-0.572, P=0.084$; males $r-0.78, P=0.008$. Panel (b): females, $r-0.426$, $P=0.22$; males, $r-0.77, P=0.009$.

\section{Methodological issues}

This is a novel approach to the investigation of protein requirements and its value depends on the extent to which the measurements of leucine balance are valid and that leucine balance can be used as an indication of protein balance. The assumptions and isotoperelated problems of amino acid turnover studies have been extensively reviewed (Bier $e t a l$. 
1985; Millward \& Rivers, 1988; Millward et al. 1991; Price et al. 1994; Gibson et al. 1996). In fact calculation of $\left[{ }^{13} \mathrm{C}\right]$ leucine tracer balance is uncomplicated kinetically with no assumptions required about the steady state. Also the potential tracer problem associated with splanchnic utilization of dietary leucine (the first-pass effect) should not in theory influence leucine oxidation and balance. However the major assumptions made here which require examination are: (1) that leucine balance measured during $1 \mathrm{~h}$ at the end of the postabsorptive phase can be used to predict the entire postabsorptive balance and (2) that the efficiency of PPU measured in this standardized protocol accurately predicts any variation in efficiency during usual meal consumption.

The first assumption was extensively investigated and confirmed in $12+12 \mathrm{~h}$ fastingfeeding studies by El Khoury et al. (1994) showing a measured postabsorptive rate of $34.7 \mathrm{mg}$ leucine compared with $32.5 \mathrm{mg}$ predicted from the final $1 \mathrm{~h}$ value. However the pattern of changes in postabsorptive leucine oxidation could differ in the elderly compared with younger adults. A continuing fall in postabsorptive leucine oxidation in the elderly compared with the initial fall to a stable low level as reported in young adults by El Khoury et al. (1994) would mean that our predicted $12 \mathrm{~h}$ value would be lower than the actual value in the elderly and would account for our findings. While such a pattern of postabsorptive leucine oxidation could mean that we have overestimated the difference between the young and elderly it is highly unlikely that the overall postabsorptive oxidation rate was higher in the elderly than the younger adults. For this to be the case postabsorptive leucine oxidation would need to remain high for most of the period and then fall rapidly to the low observed level, an unlikely but not impossible pattern of change.

As to the second assumption, that PPU measured here predicts normal meal protein utilization, it might be thought that the imposition of the LP before the HP feeding could influence leucine oxidation and balance with the HP meal compared with a simple $4+4 \mathrm{~h}$ fast-feed regimen. As discussed elsewhere (Gibson et al. 1996) we think this unlikely. In fact the value for PPU of milk calculated from a simple fasted-fed regimen (Price et al. 1994), was 0.80 (see Millward \& Pacy, 1995) compared with the mean value of 0.85 in the present study. As to the composition of the food in the elderly compared with the younger adults, while protein intakes were not different, the lower estimated energy needs meant a higher $\mathbf{P}$ : E ratio in the elderly (about $30 \%$, see Table 2). This might also be predicted for habitual diets of the elderly with the same protein intake and a lower energy expenditure. An alternative design would have been to give excess energy to the elderly group to normalize their $\mathrm{P}$ : E ratio with that of the younger adults. The probable effect of this would have been to increase the value of $P P U_{\text {meal }}$ which would have reduced the overall value of the apparent protein requirement. This would have strengthened our finding that the apparent protein requirement was not increased in the elderly.

From this we would conclude that our measures of postabsorptive leucine oxidation and the efficiency of postprandial leucine gain are valid measures and at the very least yield data which reflect any comparative values between groups. The validity of our calculations of metabolic demands and apparent protein requirements depends on the relationship between leucine oxidation and balance and protein balance.

Given the small free-pool size of leucine, changes in leucine balance reported here must reflect changes in body protein. Thus the mean rate of postabsorptive leucine oxidation (corrected for tracer) is equivalent to about $270 \mu \mathrm{mol}$ leucine/kg FFM per $12 \mathrm{~h}$, equivalent to about three times the total leucine pool size assuming an intracellularextracellular concentration gradient of 1.8 and a distribution space of 0.75 litres $/ \mathrm{kg}$ FFM. The lower postabsorptive loss in the elderly, a major finding of the present study, indicates a value of $220 \mu \mathrm{mol}$ leucine/kg FFM per $12 \mathrm{~h}$ compared with $320 \mu \mathrm{mol}$ in the young adults. 
The difference, $100 \mu \mathrm{mol}$, is an amount equal to the estimated leucine pool size so that it is not possible to explain the difference in terms of changes in the free leucine pool. Thus, it is difficult to escape the conclusion that the postabsorptive loss of protein is lower in the elderly.

In the postprandial state there is an added complication relating to any differences in the composition of the food protein compared with that of the postprandial protein gain. Our milk-protein-based diets contain higher leucine concentrations (13\%) than average mixed tissue protein, and this excess leucine will need to be oxidized (see Price et al. 1994) and this will underestimate PPU. The extent of this cannot be predicted precisely since the actual amino acid composition of postprandial gain is not known, but a $13 \%$ excess food leucine would imply a true PPU $\mathrm{Peal}_{\text {me }}$ of 0.95 compared with our mean $\mathrm{PPU}_{\text {meal }}$ value of 0.84 (see Price et al. 1994). This would lower the values of the apparent protein requirement reported here by $13 \%$. However any such error is unlikely to vary between the young and elderly and in any case we found no age-related difference in the mean values for PPU.

One final methodological consideration is the $\mathrm{N}$ balance model of Jackson (1993, 1995) which is fundamentally different from the one implicit in our studies. In the Jackson model, leucine oxidation, and amino acid oxidation in general, is not directly linked to $\mathrm{N}$ balance (see Jackson, 1993, 1995). Instead $\mathbf{N}$ balance is postulated to be regulated primarily at the level of urea salvage rather than urea synthesis as in the traditional model, with variable rates of $\mathbf{N}$ excretion and balance mediated by variable rates of urea salvage with relatively constant rates of urea production. For this model to be valid urea salvage must lead to de novo synthesis of indispensable amino acids including leucine so that protein balance can only be calculated from leucine balance if the de novo leucine synthesis is included in the balance calculation. Without this adjustment leucine oxidation would be greater and leucine balance would be less than expected (e.g. from $\mathrm{N}$ balance) and our interpretation of leucine as a measure of $\mathrm{N}$ balance would be seriously flawed as stated by Jackson $(1993,1995)$. While our own preliminary data from [ $\left.{ }^{13} \mathrm{~N}\right]$ urea studies in malnourished infants do support de novo synthesis of lysine (Yeboah et al. 1996) in support of the concept of de novo synthesis of indispensable amino acids, careful investigations of $\mathrm{N}$ and leucine balance in adults do not support the Jackson hypothesis (Price et al. 1994). Thus leucine oxidation was always less $(20 \%)$ rather than excessive compared with $\mathrm{N}$ excretion, even at low protein intakes, the opposite of what would be expected if the Jackson hypothesis were true for adults. We would conclude from this that in adults leucine balance can be used to measure whole-body protein balance in the way we have described here.

\section{The elderly subjects}

The elderly population comprises considerable heterogeneity of physiological state. The subjects examined here were recruited from a healthy, mobile population, all but one taking regular exercise and 'health conscious' by our subjective judgement. The most important issue relates to their body composition and the relatively small fall in lean body mass. Because of this the fall with age in the metabolic demand was significant both in terms of body weight and when expressed per $\mathrm{kg} \mathrm{FFM.}$

Cross-sectional and longitudinal body composition studies of the elderly (e.g. Forbes \& Reiner, 1970; Steen et al. 1979) indicate an overall decline in the lean body mass due to a selective loss of skeletal muscle mass, sarcopenia (Evans \& Campbell, 1993), from $45 \%$ in the young adult, to less than $27 \%$ of body weight after the age of 70 years, with little 
evidence for loss of non-muscle tissue (Cohn et al. 1980). In fact in the elderly subjects examined here there was little evidence of sufficient sarcopenia to reduce the overall FFM. While the elderly group were shorter, had higher BMI and percentage body fat compared with the young subjects, the two age groups did not different significantly with respect to overall BW or total FFM. On the basis of the height of the subjects, FFM was not reduced, i.e. values for $\mathrm{kg} \mathrm{FFM} /$ height $^{2}$ were 16.4 (SD 1.2) and 17.8 (SD 1.2) in young and elderly women and 18.9 (SD 0.7) and 20.2 (SD 1.3) in young and elderly men. As indicated earlier the subjects took regular exercise although none reported that they participated in any strength-training exercise regimens which have been observed to reverse the age-related decline in skeletal muscle mass. However with the shrinkage of height which occurs with age these values may well be overestimates for the elderly and it is possible that the elderly subjects represented an initially larger group and had nevertheless lost FFM and muscle mass.

Measurement of body composition in the elderly is difficult. Four elderly subjects (two men and two women) were unable to undergo underwater weighing. In these cases the less invasive bioelectrical impedance method was employed. While some investigators place little reliance on bioelectrical impedance, others such as Reilly et al. (1994) conclude that there are not large systematic differences between densitometry and bioelectrical impedance and on this basis we have compiled values for percentage body fat using these two methodologies. Densitometry, as used here for most subjects $(16 / 20)$, requires assumptions about bone mineral mass and if this is overestimated then body fat is overestimated and vice versa. In fact in the elderly men, body fat was relatively modest and not different from the levels in the young men. Percentage fat was significantly increased in the elderly women so that it is possible that this was an artifact associated with osteoporosis and that the FFM was a slightly higher proportion of body weight than calculated. However, this would have increased the observed age-related fall in metabolic demands (Table 6) and on this basis we would conclude that our finding of a fall in metabolic demands with age is secure.

\section{Age-related changes in metabolic demand}

It is clear from Fig. 3 that there was a wider range of values for the apparent protein requirement in the elderly compared with the young adults and we have examined the anthropological and biochemical characteristics of the subjects to identify any relationships with the apparent requirement. For the group as a whole $(n 20)$ metabolic demand was not related to any index of size or body composition nor to the $P: E$ ratio of the HP diet (although variation in this latter variable was small). However PPU meal $_{\text {was significantly }}$ related to both height $(r 0.452, P=0.045)$ and FFM $(r 0.544, P=0.013)$ and calculation of FFM/height ${ }^{2}$, an index comparable to BMI, indicated a significant inverse relationship between the apparent protein requirement and FFM/height ${ }^{2}(r-0.0465, P=0.0386)$. However there is no obvious biological explanation for this statistical relationship and in any case amongst the elderly $(n 10)$ there were no significant relationships between either metabolic demand or apparent protein requirement and any anthropometric or biochemical measurement.

There is no obvious explanation for a fall in metabolic demand of the extent identified here. Since our requirements model includes a large component of metabolic demand for protein which varies with habitual protein intake it is possible that the lower apparent protein requirement in the elderly men was due to a lower habitual protein intake compared with our estimated value. This was based on $3 \mathrm{~d}$ measurements of $\mathrm{N}$ excretion and since our 
subjects were an extremely compliant group with no infirm or mentally confused subjects, we have no reason to believe that serious under-collection occurred. Overall $\mathrm{N}$ balance varies from day to day, so that on any one day excretion may underestimate intake and the daily CV can be as high as $20 \%$ (Rand et al. 1981). Such errors fall markedly as the collection period is extended and over $3 \mathrm{~d}$ a systematic error is unlikely.

For some components of the miscellaneous obligatory $\mathrm{N}$ losses, for example hair, skin and nails, a fall with age might be predicted although measurements by Calloway on young (Calloway et al. 1971) and older subjects (Zanni et al. 1979) showed slightly higher values. However such differences are of minor importance compared with the fall observed here which, at about $50 \mathrm{mg} \mathrm{N} / \mathrm{kg}$, is equivalent to the entire obligatory losses. The metabolic demand includes both postabsorptive and postprandial amino acid oxidation but within the metabolic model it is calculated from postabsorptive rates. It may be that the ability to maintain protein balance in the postabsorptive state is variable between tissues so that changes in the relative amounts of skeletal muscle and visceral tissue with age could influence overall metabolic demands. In humans the relative losses of tissue protein from different tissues are not known but in animals short-term losses from visceral tissues with fasting are generally more rapid than from skeletal muscle (Waterlow et al. 1978). With sarcopenia therefore an increased postabsorptive loss per kg FFM might be expected, the opposite of that observed here. Finally, a shift in the pattern of distribution of overall amino acid oxidative losses from the postabsorptive to postprandial state would result in a lower metabolic demand as calculated here from the postabsorptive losses. However if this occurred then the increased postprandial losses would result in an apparent decrease in the efficiency of protein utilization and there would be an inverse relationship between metabolic demand and PPU. In fact no such relationship was observed $(r 0.189, P=0.424)$. Lower postabsorptive losses indicate a lower rate of proteolysis in relation to the prevailing rate of protein synthesis. The extent to which this is apparent and the other changes in protein turnover observed in these studies will be discussed in detail in a subsequent paper.

In conclusion, in this group of healthy mobile elderly men and women consuming similar protein intakes of about $1.18 \mathrm{~g}$ protein $/ \mathrm{kg}$ per $\mathrm{d}$, metabolic demands as indicated by postabsorptive leucine oxidation rates were lower and the efficiency of protein utilization was slightly lower, though not significantly so, than those in young adults. As a result apparent protein requirements were either unchanged in women at 0.85 (SD 0.27$) \mathrm{g} / \mathrm{kg}$ per d or significantly reduced in men from 0.99 (SD 0.09) $\mathrm{g} / \mathrm{kg}$ per $\mathrm{d}$ in young men to 0.66 (SD $0.21) \mathrm{g} / \mathrm{kg}$ per $\mathrm{d}$ in elderly men, and these conclusions were the same when calculated on a BW or FFM basis. It remains to be seen whether the same pattern of results is observed in the less mobile elderly.

This work was supported by a PhD studentship to AF from Research into Ageing, Help the Aged and the Nestlé Foundation. NG was supported by a Medical Research Council studentship.

\section{REFERENCES}

Abumrad, N. N., Rabin, D., Diamond, M. P. \& Lacy, W. W. (1981). Use of a heated superficial hand vein as an alternative site for the measurement of amino acid concentration and for the study of glucose and alanine kinetics in man. Metabolism Clinical and Experimental 30, 936-940.

Bier, D. M., Matthews, D. E. \& Young, V. R. (1985). Interpretation of amino acid kinetic studies in the context of whole-body protein metabolism. In Substrate and Energy Metabolism in Man, pp. 27--36 [J. S. Garrow and D. Halliday, editors]. London and Paris: John Libbey.

Calloway, D. H., Odell, A. C. F. \& Margen, S. (1971). Sweat and miscellaneous N losses in human balance studies. Journal of Nutrition 101, 775-786. 
Campbell, W. W., Crim, M. C., Dallal, G. E., Young, V. R. \& Evans, W. J. (1994). Increased protein requirements in elderly people: new data and retrospective reassessments. American Journal of Clinical Nutrition 60, 501-509.

Campbell, W. W. \& Evans, W. J. (1996). Protein requirements of elderly people. European Journal of Clinical Nutrition 50, Suppl. 1, S180-S185.

Cohn, S. H., Vartsky, D., Yasumura, S., Sawitsky, A., Zanzi, I., Vaswani, A. \& Ellis, K. J. (1980). Compartmental body composition based on total-body $\mathrm{N}$, potassium and calcium. American Journal of Physiology 239, E524-E530.

El Khoury, A. E., Fukagawa, N. K., Sanchez, M., Tsay, R. M., Gleason, R. E., Chapman, T. E. \& Young, V. R. (1994). The $24 \mathrm{hr}$ pattern and rate of leucine oxidation with particular reference to tracer estimates of leucine requirements. American Journal of Clinical Nutrition 59, 1012-1020.

Evans, W. J. \& Campbell, W. W. (1993). Sarcopenia and age-related changes in body composition and functional capacity. Journal of Nutrition 123, 465-468.

Fereday, A., Gibson, N. R., Cox, M., Halliday, D., Pacy, P. J. \& Millward, D. J. (1994). Postprandial protein utilization in the elderly. Proceedings of the Nutrition Society 53, 202A.

Food and Agriculture Organization/World Health Organization (1991). Protein Quality Evaluation. FAO Food and Nutrition Paper no. 51. Rome: FAO.

Food and Agriculture Organization/World Health Organization/United Nations University (1985). Energy and Protein Requirements. Technical Report Series no. 724. Geneva: World Health Organization.

Forbes, G. B. \& Reiner, J. C. (1970). Adult lean body mass declines with age: some longitudinal observations. Metabolism 19, 653-663.

Gibson, N. R., Fereday, A., Cox, M., Halliday, D., Pacy, P. J. \& Millward, D. J. (1996). Influences of dietary energy and protein on leucine kinetics during feeding in healthy adults. American Journal of Physiology 33, 282-291.

Jackson, A. A. (1993). Chronic malnutrition: protein metabolism. Proceedings of the Nutrition Society 52, 1-10.

Jackson, A. A. (1995). Is leucine produced by the colonic microflora? American Journal of Clinical Nutrition 62 , 977-978.

Millward, D. J., Jackson, A. A., Price, G. \& Rivers, J. P. W. (1989). Human amino acid and protein requirements: current dilemmas and uncertainties. Nutrition Research Reviews 2, 109-132.

Millward, D. J. \& Pacy, P. J. (1995). Postprandial protein utilisation and protein quality assessment in man. Clinical Science 88, 597-606.

Millward, D. J., Price, G., Pacy, P. J. H. \& Halliday, D. (1991). Whole body protein and amino acid turnover in man: what can we measure with confidence? Proceedings of the Nutrition Society 50, 195-214.

Millward, D. J. \& Rivers, J. (1988). The nutritional role of indispensible amino acids and the metabolic basis for their requirements. European Journal of Clinical Nutrition 42, 367-393.

Millward, D. J. \& Roberts, S. B. (1996). Protein requirements of older individuals. Nutrition Research Reviews 9, 67-87.

Pacy, P. J., Price, G. M., Halliday, D., Quevedo, M. R. \& Millward, D. J. (1994). N homeostasis in man: 2. The diurnal responses of protein synthesis, degradation and amino acid oxidation to diets with increasing protein intakes. Clinical Science 86, 103-118.

Pacy, P., Quevedo, R. M., Gibson, N. R., Cox, M., Koutedakis, Y. \& Millward, D. J. (1995). Body composition measurements in international heavyweight oarswomen: a comparison of five methods.The Journal of Sports Medicine and Physical Fitness 35, 67-74.

Price, G. M., Halliday, D., Pacy, P. J., Quevedo, M. R. \& Millward, D. J. (1994). N homeostasis in man: influence of protein intake on the amplitude of diurnal cycling of body N. Clinical Science 86, 91-102.

Quevedo, M. R., Price, G. M., Halliday, D., Pacy, P. J. \& Millward, D. J. (1994). N homeostasis in man: 3. Diurnal changes in $\mathrm{N}$ excretion, leucine oxidation and whole body leucine kinetics during a reduction from a high to a moderate protein intake. Clinical Science 86, 185-193.

Rand, W. M., Scrimshaw, N. S. \& Young, V. R. (1981). Conventional long term N balance studies for protein quality evaluation in adults: rationale and limitations. In Protein Quality in Humans: Assessment and In Vitro Estimation, pp. 59-97 [C. E. Bodwell, J. S. Atkins and D. T. Hopkins, editors]. Westport, CT: The AUI Publishing Co. Inc.

Reilly, J. J., Murray, L. A., Wilson, J. \& Durnin, J. V. G. A. (1994). Measuring the body composition of elderly subjects: a comparison of methods. British Journal of Nutrition 72, 33-44.

Siri, W. E. (1961). Body composition from fluid spaces and density; analysis of methods. In Techniques for Measuring Body Composition, pp. 223-244 [J. Brozek and A. Henschel, editors]. Washington, DC: National Academy of Sciences.

Steen, G., Isaksson, B. \& Svanborg, A. (1979). Body composition at 70 and 75 years of age: a longitudinal population study. Journal of Clinical Experimental Gerontology 1, 185-200.

Waterlow, J. C., Garlick, P. J. \& Millward, D. J. (1978). Protein Turnover in Mammalian Tissues and in the Whole Body. Amsterdam: Elsevier/North-Holland Biomedical Press. 
Wenham, D., Pacy, P., Price, G. M., Millward, D. J. \& Halliday, D. (1991). Bicarbonate recovery during feeding and fasting. Proceedings of the Nutrition Society 50, 47A.

Yeboah, N., Ah-Sing, E., Badalloo, A., Forrester, T., Jackson, A. \& Millward, D. J. (1996). Transfer of ${ }^{15} \mathrm{~N}$ from urea to the circulating lysine pool in the human infant. Proceedings of the Nutrition Society 55, 37A.

Zanni, E., Calloway, D. H. \& Zezulka, A. Y. (1979). Protein requirements of elderly men. Journal of Nutrition 109, 513-524. 